\title{
Two species of Naididae (Annelida, Clitellata) from southern Tibet, China
}

\author{
Yu Peng ${ }^{1,2}$, Hongzhu Wang', Yongde Cui' \\ I State Key Laboratory of Freshwater Ecology and Biotechnology, Institute of Hydrobiology, Chinese Academy of \\ Sciences, Wuban 430072, China 2 University of Chinese Academy of Sciences, Beijing 100049, China \\ Corresponding author: Yongde Cui (ydcui@ihb.ac.cn)
}

Academic editor: R. Blakemore | Received 15 July 2014 | Accepted 1 September 2014 | Published 7 October 2014

http://zoobank.org/2312CD01-A2D4-46A8-8A50-37E24B07AB68

Citation: Peng Y, Wang HZ, Cui YD (2014) Two species of Naididae (Annelida, Clitellata) from southern Tibet, China. ZooKeys 444: 59-68. doi: 10.3897/zookeys.444.8285

\begin{abstract}
One new species of Naidinae (Oligochaeta, Naididae), Nais badia sp. n. and one new record species from China, Tubifex montanus Kowalewski, 1919 (Tubificinae) are found in southern Tibet. The new species is distinguished from congeners by its large area of reddish brown pigment in the anterior segments I-VIII, serrate hairs, pectinate needles with 1-2 intermediate teeth, ventral chaetae partly with 1-2 fine intermediate teeth and wave-like movements. The new material of the species Tubifex montanus differs slightly from the previous descriptions by its vas deferens entering atrium subapically, wide ental end of penial sheath and smooth hair chaetae.
\end{abstract}

\section{Keywords}

Nais badia, Tubifex montanus, Naididae, new species, new record species, taxonomy, southern Tibet

\section{Introduction}

The Tibetan Plateau is one of the biodiversity hotspots around the globe for its unique natural environment ( $\mathrm{Li}$ and Fang 1999), which accounts for the rich occurrence of endemic species of various taxa in this region, such as Triplophysa cakaensis (Cobitidae) (Cao and Zhu 1988), Schizothorax waltoni (Cyprinidae) (Chen and Chen 2010), and Alona aliensis (Chydoridae) (Chiang et al. 1983). What about oligochaetes? In the 20th century, there were only seven species of oligochaetes recorded in Tibet (Stephenson 1909; Černosvitov 1942; Liang 1963, 1979; Liang et al. 1998). Recently, He recorded 26 species in Tibet (He 2011; He et al. 2012), though focusing mainly on large rivers

Copyright Yu Peng et al. This is an open access article distributed under the terms of the Creative Commons Attribution License (CC BY 4.0), which permits unrestricted use, distribution, and reproduction in any medium, provided the original author and source are credited. 
(Yarlung Zangbo River) and brackish lakes (Lake Nam Co and Lake Yamzho Yumco). Some freshwater wetlands among mountains in Tibet had been neglected, which we thought may be the ideal habitats for aquatic oligochaetes. In this paper, we describe one new species, Nais badia sp. n., and one new record of Tubifex montanus Kowalewski, 1919 found in a freshwater wetland of Cuomujiri Mountain, southern Tibet.

\section{Materials and methods}

The sampling site was in a wetland of Cuomujiri Mountain, southern Tibet of China. $\left(29^{\circ} 47^{\prime} 46^{\prime \prime} \mathrm{N}, 94^{\circ} 24^{\prime} 53 " \mathrm{E}\right)$, ca 3,990 $\mathrm{m}$ above sea level. The substrate type was silt, and hydrophytes were abundant. Water depth was $10-20 \mathrm{~cm}$, water temperature $11.5^{\circ} \mathrm{C}$, $\mathrm{pH} 6.23$, dissolved oxygen $9.14 \mathrm{mg} / \mathrm{L}$, and conductivity $19.3 \mu \mathrm{s} / \mathrm{cm}$.

The samples were collected with a D-frame dip net, and cleaned through a $250 \mu \mathrm{m}$ sieve. Large worms were sorted in a white porcelain dish manually and small individuals were sorted with a dissecting microscope. Specimens were all preserved in 10\% formalin. Some specimens were investigated with a Scanning Election Microscopy (SEM) to reveal more details of the chaetae. Some were stained with borax carmine, dehydrated in a series of alcohol, cleared in xylene and mounted whole in Canada balsam for careful observation. Parameters of external morphology were established under glycerine mounts. Other parameters were studied on permanent mounts. Drawings were made with a camera lucida. All microscopic observations, including live observations, were documented photographically. The types and other specimens were all deposited in the Institute of Hydrobiology (IHB), Chinese Academy of Sciences (CAS), Wuhan, China.

\section{Abbreviations in the figures}

Roman numbers $=$ segment number, $\mathrm{SEM}=$ Scanning Electron Microscopy, at $=$ atri$\mathrm{um}, \mathrm{mp}=$ male pore, $\mathrm{pe}=$ penis, $\mathrm{pr}=$ prostate gland, $\mathrm{ps}=$ penial sheath, $\mathrm{sf}=$ sperm funnel, $\mathrm{sp}=$ spermatheca, $\mathrm{spp}=$ spermathecal pore, $\mathrm{vd}=$ vas deferens.

\section{Taxonomy}

\section{Family Naididae \\ Subfamily Naidinae}

\section{Nais badia sp. $\mathbf{n}$.}

http://zoobank.org/B20893C6-27F2-4BF1-8A63-FE6EDA75BCF6

Figs 1, 2, 3; Table 1

Holotype. IHB XZ20130630a, whole-mounted specimen, immature. 

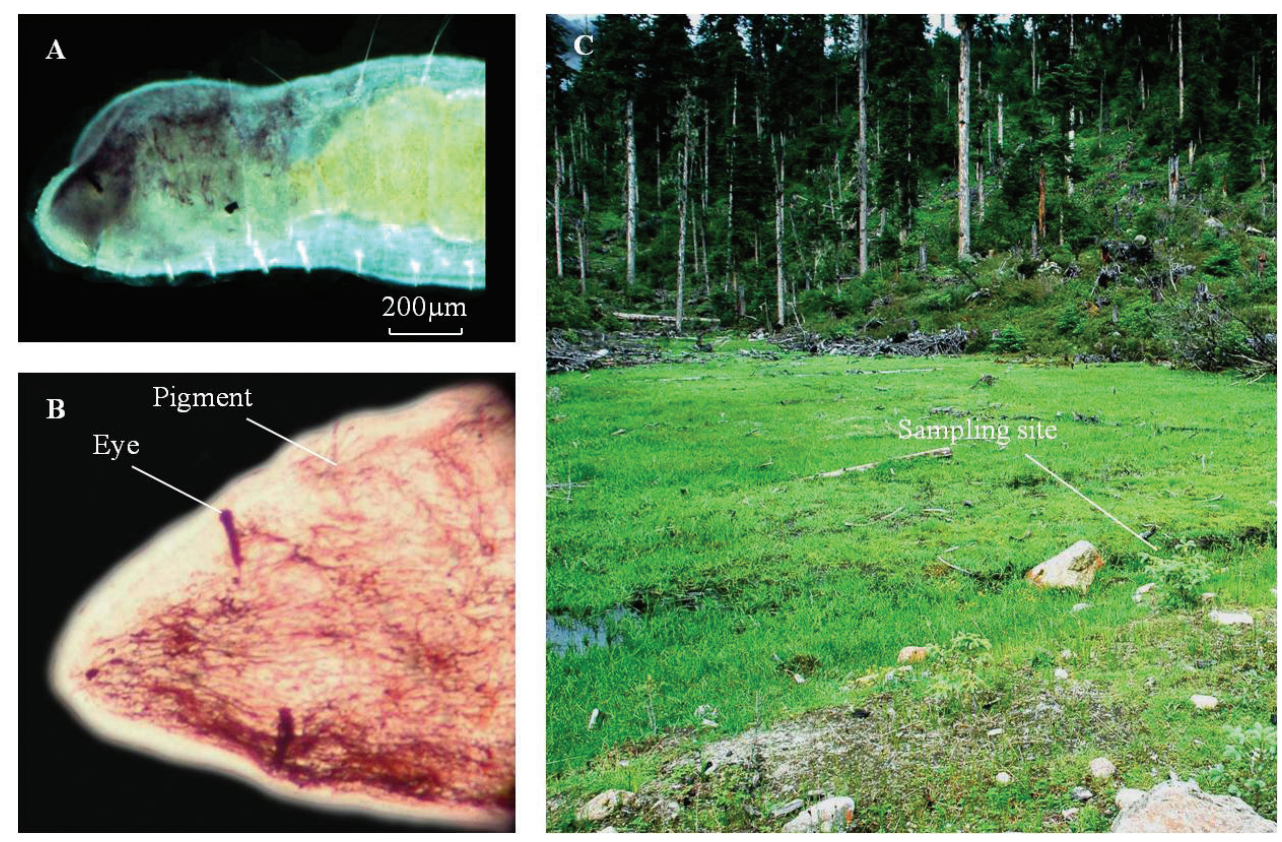

Figure I. Nais badia sp. n. A anterior reddish brown pigment in segments I-VIII B dorsal view of the head, live worm $\mathbf{C}$ habitat.

Type locality. Wetland in Cuomujiri Mountain (29.47'46"N, 94²4'53"E), southern Tibet of China. 30 June 2013, collected by H.Z. Wang, Y.D. Cui, Y.J. He and Y. Peng.

Paratypes. IHB XZ20130630b-f, 2 whole-mounted specimens (mature), 2 wholemounted specimens (immature), 1 specimen is used for scanning electron microscopy. 30 June 2013, collected from the type locality.

Other material. 40 specimens are preserved in 10\% formalin. 30 June 2013, collected from the type locality.

Etymology. The specific name "badia" is Latin for "badius", and refers to this worm's large area of reddish brown pigment in anterior segments I-VIII.

Description. Length 4.2-9.1 mm (Holotype $7.2 \mathrm{~mm}$ ), width at V $0.3-0.6 \mathrm{~mm}$ (Holotype $0.6 \mathrm{~mm}$ ). Segments 24-54 (Holotype 52). Prostomium conical, eyes present, large area of reddish brown pigment in segments I-VIII (Fig. 1A-B). Clitellum inconspicuous. Coelomocytes present. Stomach dilatation sudden in VII-VIII. Wavelike movements.

Dorsal chaetae beginning in VI onwards (Fig. 2A). Hairs (0)1-3 per bundle, 137-325 $\mu \mathrm{m}$ long, all serrate (Fig. 2B-C). Needles (0)2-3 per bundle, 80-90 $\mu \mathrm{m}$ long, distal tooth slightly longer than the proximal one (VII $3.8 \mu \mathrm{m} / 3.2 \mu \mathrm{m}$ ), completely pectinate with 1-2 intermediate teeth (Fig. 2D), nodulus often inconspicuous, $1 / 3$ from the distal end (Fig. 3C). Ventral chaetae in II-V 7-8 per bundle, the rest 2-6(7) per bundle, 105-128 $\mu \mathrm{m}$ long, distal tooth longer and thinner than the proximal one $(7.5 \mu \mathrm{m} / 5 \mu \mathrm{m})$, about $50 \%$ of ventral chaetae with $1-2$ fine inter- 

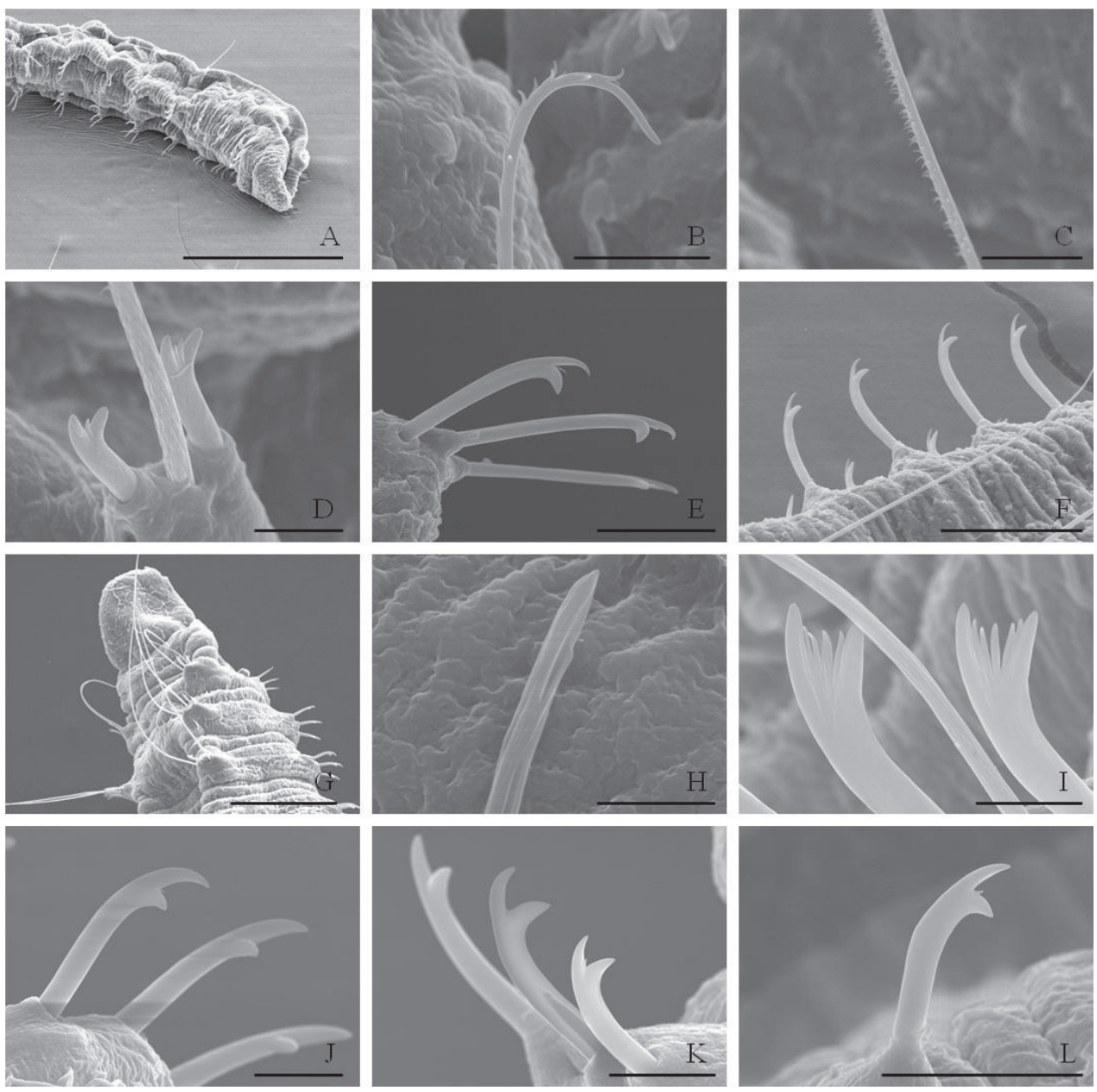

Figure 2. SEM micrographs A-F Nais badia sp. n. A lateral view of anterior body B-C hairs in VIII and VI D needles in VI E-F ventral chaetae in XIII and posterior. G-L Tubifex montanus $\mathbf{G}$ lateral view of the head $\mathbf{H}$ hairs in X $\mathbf{I}$ needles in II J-L ventral chaetae in IV, XIII and posterior. Scale bar: A $300 \mu \mathrm{m}$, B, D and $\mathbf{I} 5 \mu \mathrm{m}, \mathbf{C}$, J and $\mathbf{K} 10 \mu \mathrm{m}$, E and $\mathbf{L} 20 \mu \mathrm{m}, \mathbf{F} 40 \mu \mathrm{m}, \mathbf{G ~} 100 \mu \mathrm{m}, \mathbf{H} 2 \mu \mathrm{m}$.

mediate teeth (Fig. 2E-F), nodulus median or slightly distal (Fig. 3A-B). Penial chaetae 4 on each side in VI, with a simple hook, 115-155 $\mu \mathrm{m}$ long, 4.2-6.3 $\mu \mathrm{m}$ thick (Fig. 3D).

Pharyngeal glands in II-III. Clitellum in V-VI. Male genitalia paired in V-VI (Fig. 3E). Vasa deferentias 260-273 $\mu \mathrm{m}$ long, with prostate gland cells covering only on their posterior part, join atria subapically (Fig. 3E, vd and pr). Atrial ampullae large and ovoid, 150-160 $\mu \mathrm{m}$ long, 70-90 $\mu \mathrm{m}$ wide, ducts short and narrow (Fig. 3E, at). Spermathecal ampullae globular, length 80-100 $\mu \mathrm{m}$, width 75-90 $\mu \mathrm{m}$, spermathecal ducts long and narrow, length $60-70 \mu \mathrm{m}$, width $15-16$ $\mu \mathrm{m}$ (Fig. 3E, sp). 


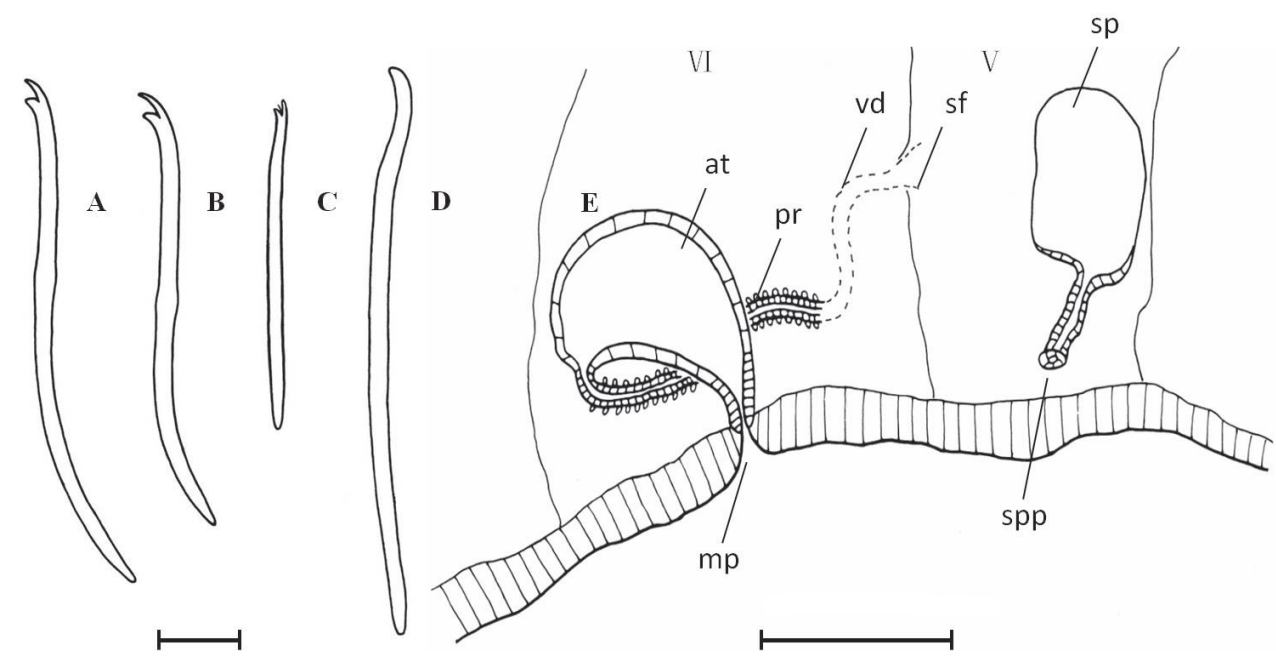

Figure 3. Nais badia sp. n. A-B ventral chaetae in V and X C dorsal bifid in X D penial chaeta in VI E lateral view of male duct and spermatheca in segments V-VI. Scale bar: A-D $20 \mu \mathrm{m}, \mathbf{E} 120 \mu \mathrm{m}$.

Distribution. Known only from Cuomujiri Mountain, southern Tibet of China. High mountain, wetland, hydrophytes abundant (Fig. 1C).

Remarks. The presence of eyes, dorsal chaetae beginning in VI consisting of hairs and double-pronged needles, pharynx in II-III, stomach beginning in VII, coelomocytes present, spermathecae with distinct ducts, male ducts paired in V-VI, vas deferens with prostate glands joining atrium subapically, atrium without prostate, penial chaetae present with a simple hook, indicate that this new species fits the definition of Nais Müller, 1773 (Sperber 1948; Brinkhurst and Jamieson 1971).

Nais badia sp. $\mathrm{n}$. is distinguished from congeners for having a large area of reddish brown pigment in anterior segments I-VIII, hairs all serrate, needles pectinate with 1-2 intermediate teeth, ventral chaetae with (0)1-2 fine intermediate teeth (Only visible under SEM) and wave-like movements (Table 1). We are hence of the opinion that it can be described as new to science.

This new species is similar to Nais africana Brinkhurst, 1966 for having pectinate needles, but differs from it by its ventral chaetae in II-V differing from the rest, although the position of Nais africana in the genus is regarded as uncertain due to a lack of detailed examination of live worms and sectioned materials (Brinkhurst 1966). Nais elinguis resembles the new species on the needles and simple pointed penial chaetae, but its long and wide atrial duct, slow stomach dilatations and the vas deferens which is completely surrounded by abundant prostate gland cells are significantly different from the new species. With regard to the vas deferens completely surrounded by prostate gland cells on their posterior part, this new species is similar to Nais communis, Nais variabilis and Nais pardalis. However, some characteristic features of these species distinguish them from the new species. Nais communis eyes are generally absent, stomach dilatations are slow and the atrium is as long as the duct. Nais variabilis, Nais pardalis 


\begin{tabular}{|c|c|c|c|c|c|c|c|c|c|c|c|c|c|}
\hline 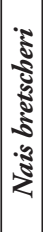 & 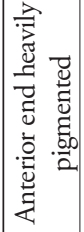 & 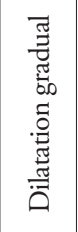 & 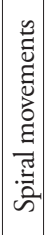 & $\sim$ & I & 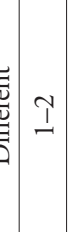 & $I$ & $\Sigma$ & 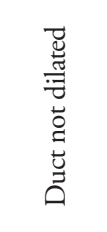 & 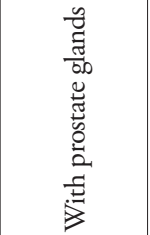 & $\begin{array}{l}\frac{\pi}{\Xi} \\
\frac{0}{0} \\
0\end{array}$ & 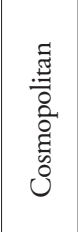 & \multirow{5}{*}{ 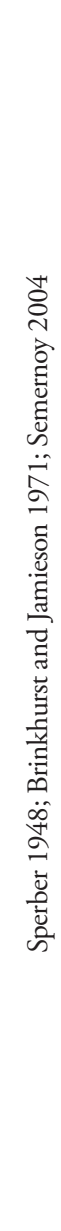 } \\
\hline 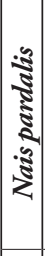 & 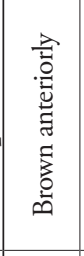 & 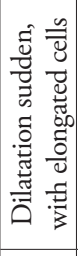 & 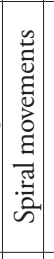 & $n$ & 乞 & 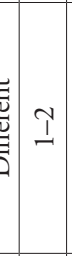 & $I$ & $\Sigma$ & 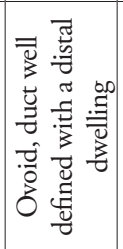 & 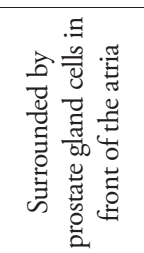 & 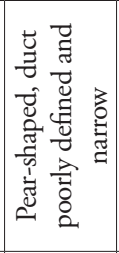 & 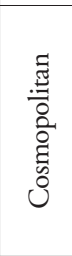 & \\
\hline 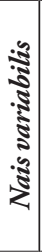 & 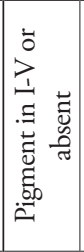 & 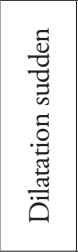 & 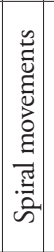 & 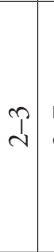 & へ & 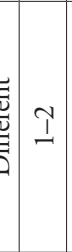 & $I$ & $\Sigma$ & 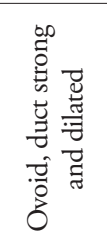 & 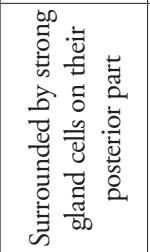 & 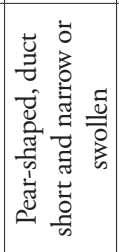 & 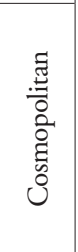 & \\
\hline 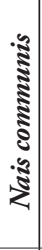 & 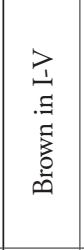 & 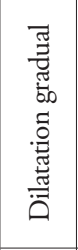 & 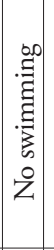 & $\stackrel{\infty}{d}$ & 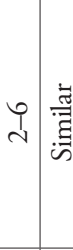 & $I$ & $I$ & & 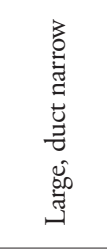 & 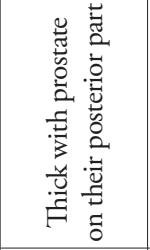 & 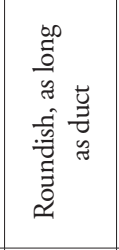 & 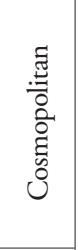 & \\
\hline 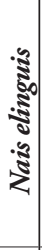 & 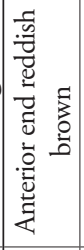 & 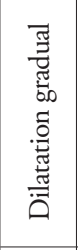 & 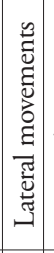 & $\tilde{f}$ & 兄 & $\stackrel{1}{1}$ & $I$ & $\Sigma$ & 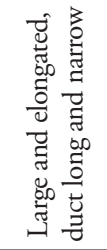 & 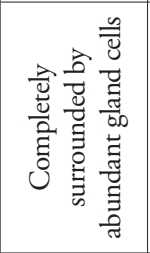 & 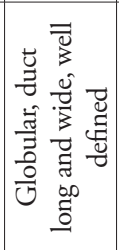 & 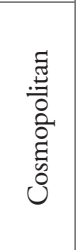 & \\
\hline 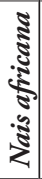 & ' & ' & 1 & 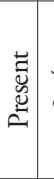 & 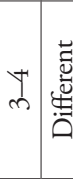 & 苞 & 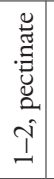 & 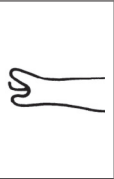 & 1 & I & ' & 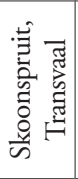 & 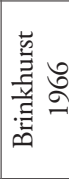 \\
\hline 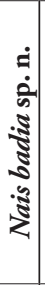 & 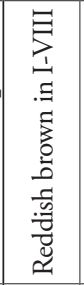 & 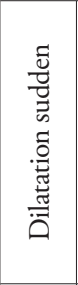 & 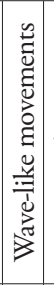 & 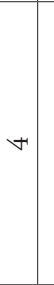 & 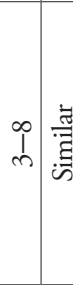 & 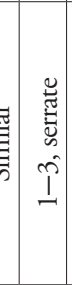 & 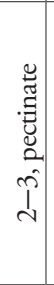 & 5 & 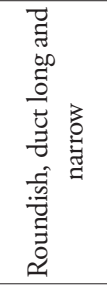 & 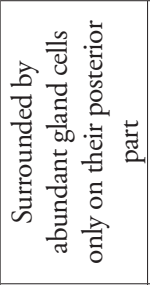 & 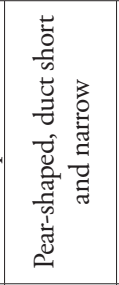 & 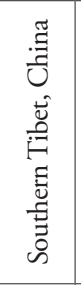 & 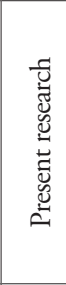 \\
\hline 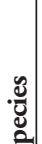 & 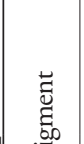 & $\begin{array}{l}\text { ज्ञ } \\
\tilde{\Xi} \\
\text { है }\end{array}$ & 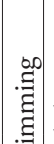 & 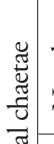 & 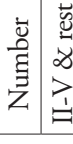 & 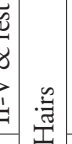 & 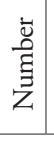 & 节 & 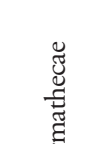 & 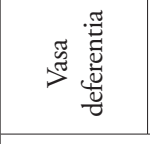 & 䍃 & 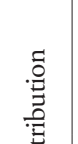 & 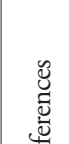 \\
\hline & $\approx$ & मे & $\mid$ & . & 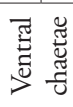 & & & $\begin{array}{l}\frac{\mathscr{u}}{\bar{z}} \\
\ddot{\breve{u}}\end{array}$ & $\begin{array}{l}\text { Ĕ } \\
\text { के }\end{array}$ & 5 & & . & $x_{1}$ \\
\hline
\end{tabular}


and Nais bretscheri all have the ventral chaetae in II-V that differ from the remaining segments. Nais pardalis the stomach has obvious elongated cells. Nais bretscheri the ventral chaetae have typical giant chaetae.

\section{Subfamily Tubificinae}

\section{Tubifex montanus Kowalewski, 1919}

Figs 2, 4; Table 2

Tubifex montanus Kowalewski: Hrabě 1939, 1981; Brinkhurst and Jamieson 1971.

Examined material. IHB XZ20130630g-i, 2 whole-mounted mature specimens although only 1 specimen has male ducts that can be observed and measured, 1 specimen is used for scanning electron microscopy. Wetland in Cuomujiri Mountain $\left(29^{\circ} 47^{\prime} 46^{\prime \prime} \mathrm{N}, 94^{\circ} 24^{\prime} 53^{\prime \prime E}\right)$ of southern Tibet, China. 30 June 2013, collected by H.Z. Wang, Y.D. Cui, Y.J. He and Y. Peng.

Description. Length $10-12 \mathrm{~mm}$, width at XI 0.4-0.7 mm. Segments 41-56. Prostomium obtuse. Clitellum inconspicuous. No coelomocytes.

Dorsal chaetae (0) 1-3 hairs and 1-3 needles per bundle. Hairs smooth (Fig. $2 \mathrm{H}-\mathrm{I}), 180-463 \mu \mathrm{m}$ long. Needles almost palmate (3-11 teeth or more, Fig. 2I and Fig. 4D), 40-100 $\mu \mathrm{m}$ long, two short outer teeth nearly equal $(7.5 \mu \mathrm{m} / 7.5 \mu \mathrm{m})$. Ventral chaetae 60-100 $\mu \mathrm{m}$ long with (0)1-2 fine intermediate teeth partly (Fig. 2J-L and Fig. 4A-C), anteriorly 3-4 per bundle with upper tooth slightly thinner than and nearly $2-3$ times as long as the lower $(7.5 \mu \mathrm{m} / 3 \mu \mathrm{m})$, in midbody $1-2$ per bundle with two nearly equal teeth $(5 \mu \mathrm{m} / 5 \mu \mathrm{m})$, posteriorly $1-2$ per bundle with upper tooth nearly 2 to 3 times as long as the lower $(5 \mu \mathrm{m} / 2 \mu \mathrm{m})$. Ventral chaetae in XI present but unmodified.

Pharyngeal glands in II-V. Chloragogen cells beginning in VI onwards. Male ducts paired in X-XI (Fig. 4F). Vas deferens $722 \mu \mathrm{m}$ long or more, nearly 2.2 times longer than the atrium, uniform and forming numerous loops in XI, ciliated throughout and entering narrow atrium subapically (Fig. 4F, vd). Atrium pear-shaped, with quite long ejaculatory duct, and gradually becomes narrower toward the ectal end, $343 \mu \mathrm{m}$ long (Fig. 4F, at). Large compact prostate gland empties into the atrial ampulla near the sperm duct outlet, $137 \mu \mathrm{m}$ long, $83 \mu \mathrm{m}$ wide (Fig. 4F, pr). Penis cylindrical, $132 \mu \mathrm{m}$ long, surrounded by a cuticularized, funnel-like penial sheath (Fig. 4E), $172 \mu \mathrm{m}$ long and $71 \mu \mathrm{m}$ wide at the ental end. Spermatheca absent. Testes paired in X. Ovaries paired in XI.

Distribution. Cuomojiri Mountain, southern Tibet of China. A wetland with abundant hydrophytes. Tatra Mountains, Europe (Hrabě 1939; Brinkhurst and Jamieson 1971).

Remarks. According to the characteristics of a long vas deferens entering pearshaped atrium subapically, large compact prostate gland with stalk-like attachments 


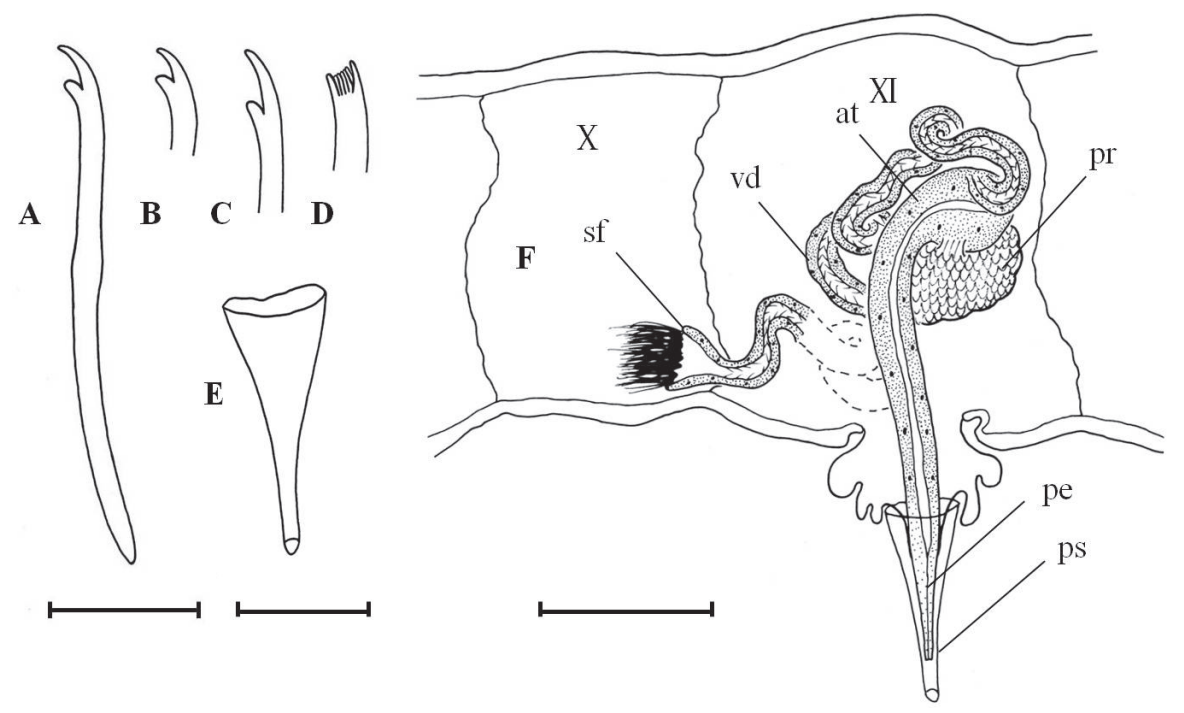

Figure 4. Tubifex montanus A-C ventral chaetae in II, XVIII and XXIX D dorsal chaetae in VI E penial sheath $\mathbf{F}$ lateral view of male duct in segments X-XI. Scale bar: A-D $20 \mu \mathrm{m}, \mathbf{E} 80 \mu \mathrm{m}, \mathbf{F} 160 \mu \mathrm{m}$.

Table 2. Comparison of Tubifex montanus from Tibet and Europe.

\begin{tabular}{|c|c|c|c|}
\hline \multicolumn{2}{|c|}{ Regions } & Tibet & Europe \\
\hline \multicolumn{2}{|c|}{ Body length $(\mathrm{mm})$} & $10-12$ & 8 to 12 \\
\hline \multicolumn{2}{|c|}{ Body width (mm) } & $0.4-0.7$ & 0.7 \\
\hline \multicolumn{2}{|c|}{ Segment number } & $41-56$ & 40 to 50 \\
\hline \multicolumn{2}{|c|}{ Chaetae } & $\begin{array}{c}\text { Hairs smooth }(1-3) \text {, needles palmate }(1-3) \text {, } \\
\text { ventral chaetae serrate partly }(1-4)\end{array}$ & $\begin{array}{c}\text { Hairs hispid (2-3), needles palmate (2-3), } \\
\text { ventral chaetae serrate }(3-5)\end{array}$ \\
\hline \multirow{4}{*}{$\begin{array}{l}\text { Male } \\
\text { ducts }\end{array}$} & $\begin{array}{c}\text { Vasa } \\
\text { deferentia }\end{array}$ & $\begin{array}{l}\text { Ciliated along entire length, all one width, } \\
\text { entering narrow atrium subapically, nearly } \\
2.2 \text { times longer than the atrium. }\end{array}$ & $\begin{array}{l}\text { Ciliated along entire length, all one width, } \\
\text { entering narrow atrium apically, nearly } 1.5 \\
\text { times longer than the atrium. }\end{array}$ \\
\hline & Atria & Pear-shaped & Asymmetrical, pear-shaped \\
\hline & $\begin{array}{l}\text { Prostate } \\
\text { glands }\end{array}$ & $\begin{array}{l}\text { Large compact prostate with stalk-like } \\
\text { attachments to atrial ampulla near sperm } \\
\text { duct outlet }\end{array}$ & $\begin{array}{l}\text { Large compact prostate empties into the } \\
\text { atrial ampulla near sperm duct outlet }\end{array}$ \\
\hline & $\begin{array}{l}\text { Penial } \\
\text { sheaths }\end{array}$ & Funnel-like, cuticular tube & Conical, somewhat bent cuticular tube \\
\hline \multicolumn{4}{|c|}{ Drawing } \\
\hline \multicolumn{2}{|c|}{ Spermathecae } & Absent & Absent \\
\hline \multicolumn{2}{|c|}{ Distribution } & Cuomujiri Mountain, southern Tibet, China & Tatra Mountains, Europe \\
\hline \multicolumn{2}{|c|}{ References } & Present research & $\begin{array}{c}\text { Hrabě 1939, 1981; Brinkhurst and } \\
\text { Jamieson } 1971\end{array}$ \\
\hline
\end{tabular}


to atrium and penis with funnel-like penial sheath, the species fits the definition of Tubifex Lamarck, 1816 (Brinkhurst and Jamieson 1971).

The new material resembles Tubifex montanus Kowalewski, 1919 in absence of spermathecae, vas deferens nearly of a similar length with cilia throughout, pear-shaped atrium with quite long ejaculatory duct gradually becoming narrower toward the ectal end, large compact prostate gland empting into the atrial ampullae near the sperm duct outlet, cylindrical penis, surrounded by cuticularized and funnel-like penial sheath, and nearly the same type of dorsal ventral chaetae (Table 2).

However, the new material differs slightly from the description by Hraber (1939, 1981) by having the vas deferens entering the atrium subapically, straight penis sheath with ental end wider and smooth hair chaetae.

\section{Acknowledgement}

We gratefully acknowledge Dr Xuebao He (Third Institute of Oceanography, State Oceanic Administration) and three anonymous reviewers for their invaluable comments on the manuscript. We also thank Ms Yajing He (IHB, CAS) for her help in collecting samples. Financial support was provided by the Knowledge Innovation Program of the Chinese Academy of Sciences and National Natural Science Foundation of China (No.31 100407).

\section{References}

Brinkhurst RO (1966) A contribution towards a revision of the aquatic Oligochaeta of Africa. Zoologica Africana 2: 131-166.

Brinkhurst RO, Jamieson BGM (1971) Aquatic Oligochaeta of the World. Oliver and Boyd, Edinburgh, 860 pp.

Cao WX, Zhu SQ (1988) Two new species of genus Triplophysa from Qinghai-Tibet Plateau, China. Acta Zoologica Sinica 13: 201-204. [in Chinese with English abstract]

Černosvitov L (1942) Oligochaeta from Tibet. Proceedings of Zoological Society of London 111: 281-287.

Chen F, Chen YF (2010) Investigation and protection strategies of fishes of Lhasa River. Acta Hydrobiologica Sinica 34(2): 278-285. doi: 10.3724/SP.J.1035.2009.00278 [in Chinese with English abstract]

Chiang SZ, Shen YF, Gong XJ (1983) Aquatic invertebrates of the Tibetan Plateau. The Series of the Scientific Expedition to Qinghai-Xizang Plateau. Academia Sinica, Beijing, 492 pp. [in Chinese]

He XB (2011) Studies on Faunae of Aquatic Oligochaeta (Annelida) in Tibet and Four Large Rivers of China. PhD Thesis, Institute of Hydrobiology, Chinese Academy of Sciences, 210 pp. [in Chinese with English abstract]

He XB, Cui YD, Wang HZ (2012) Two new species of Tubificinae (Annelida, Clitellata, Naididae) from Tibet, China. Zootaxa 3458: 159-165. 
Hrabě S (1939) Oligochètes aquatiques des Hautes Tatras. Věstnik. Československé Zoologické Společnosti 6/7: 209-236.

Hrabě S (1981) Vodní máloštětinatci (Oligochaeta) Československa. Acta Universitatis Carolinae Biologica 1979: 1-167.

Li JJ, Fang XM (1999) Uplift of the Tibetan Plateau and environmental changes. Chinese Science Bulletin 44(23): 2117-2124. doi: 10.1007/BF03182692

Liang YL (1963) Studies on the aquatic Oligochaeta of China I. Descriptions of new naids and branchiobdellids. Acta Zoologica Sinica 15: 560-570. [in Chinese with English abstract]

Liang YL, Fang ZC, Zhang TN (1979) A new genus and species of Enchytraeidae from Tibet. Acta Zootaxonomica Sinica 4: 312-315. [in Chinese with English abstract]

Liang YL, Wang HZ, Xie ZC (1998) Studies on the aquatic Oligochaeta of China IV. Diagnoses of new records and rare species of Naididae and Tubificidae. Acta Hydrobiologica Sinica 22: 54-61. [in Chinese with English abstract]

Semernoy VP (2004) Oligochaeta of Lake Baikal. Nauka, Novosibirsk, 528 pp. [in Russian]

Sperber C (1948) A taxonomical study of the Naididae. Zoologiska Bidrag Uppsala 28: 1-296.

Stephenson J (1909) Report on a collection of smaller Oligochaeta made by Captain FH, Stewart IMS, in Tibet. Records of the Indian Museum 3(2): 105-114. 